\title{
Assessing Mercury Content in Plant and Animal Raw Materials in an Area Impacted by the Copper Industry
}

\author{
Zbigniew Dobrzański ${ }^{1}$, Roman Kołacz', Stanisław Czaban², Fabiola Bubel ${ }^{1}$, \\ Mateusz Malczewski ${ }^{3}$, Robert Kupczyński ${ }^{1}$, Sebastian Opaliński ${ }^{1 *}$ \\ ${ }^{1}$ Department of Environment, Animal Hygiene and Welfare, Faculty of Biology and Animal Science, \\ Wroclaw University of Environmental and Life Sciences, \\ Chełmońskiego 38C, 51-630 Wrocław, Poland \\ ${ }^{2}$ Institute of Environmental Engineering, Faculty of Environmental Engineering and Geodesy, \\ Wrocław University of Environmental and Life Sciences, \\ Grunwaldzka 24, 50-363 Wroclaw, Poland \\ ${ }^{3}$ KGHM Polska Miedź S.A., Hydrotechnical Unit, \\ Polkowicka 52, 59-305 Rudna, Poland
}

Received: 30 August 2016

Accepted: 3 November 2016

\begin{abstract}
We used a mercury analyzer to determine total mercury $(\mathrm{Hg})$ content in samples of plants and animal origin raw materials collected from an area impacted by the copper industry (Legnica-Głogów Copper District). In 2014 and 2015 we analyzed samples of wheat (grain); potatoes (tuber); dry grass (hay); cow milk, hair, and blood; and poultry liver, muscles, and eggs from 14 villages. Generally, no increased $\mathrm{Hg}$ concentrations in the analyzed samples were found. There were no significant differences between the examined years. The highest content of $\mathrm{Hg}$ was found in grass (hay) and cow's hair. There was a many-fold decrease of mercury concentrations in cereals, cow milk, and poultry (eggs, muscles, liver) in comparison to previous studies (2002-07), which indirectly proves that the environmental efforts led by local authorities and industry have been effective.
\end{abstract}

Keywords: copper industry, total mercury, plant, livestock

\section{Introduction}

Mercury belongs to the group of toxic metals and it exhibits strong chemical and biological activity and variability of its form (liquid and gas). It is not needed

*e-mail: sebastian.opalinski@up.wroc.pl in the life processes of plants, animals, and humans. Mercury is toxic to the environment - especially in its organic forms (methyl mercury, ethyl mercury, phenyl mercury, etc.) [1-3]. The phytotoxic and genotoxic activity of $\mathrm{Hg}$ (and its compounds) is well documented [4-6], and the International Agency for Research of Cancer (IARC, Lyon, France) qualified organic mercury (methylmercury) compounds to group $2 \mathrm{~B}$, meaning that they are possibly carcinogenic to humans [7]. 
Mercury is transferred between air, soil, and plants, and originates from several sources. Natural $\mathrm{Hg}$ sources include cannabar (ore) and fossil fuels such as coal or petroleum, as well as volcano eruptions and forest fires. Mercury content in the environment has been increasing due to discharge from hydroelectric, mining (mainly small-scale gold refining and processing), pulp and paper industries. Incineration of municipal and medical waste and emissions from coal-burning power plants also contribute to high levels of mercury [8-9].

It is difficult to evaluate the total global annual emissions of mercury with high precision, both from natural and anthropogenic sources, but it was estimated at the end of the 20th century on the level of between 4,400 and 7,500 Mg per year [10]. According to other data, global mercury emission to the atmosphere in 2010 only from major anthropogenic sectors (including artisanal and small-scale gold mining, coal combustion, non-ferrous metals, cement production, etc.) was between 1,010 and $4,070 \mathrm{Mg}$ [9]. In Poland, according to different scenarios, $\mathrm{Hg}$ annual emissions in 2020 will be between 8.2 (MFTR restrictive scenario) and $21.6 \mathrm{Mg}$ (SQ scenario), while for the base year 2005 it was estimated to be $21.2 \mathrm{Mg}$ [11]. The mercury emission forecast from 10 European countries (including Poland) with the largest emission assumes its reduction to $179.6 \mathrm{Mg}$ per year (BAU scenario) or 64.4 Mg per year (DEG scenario) in 2020 [12-13]. The issue of mercury is of particular interest in the European Union, thus a special CONTAM panel of EFSA (European Food Safety Authority), which is monitoring contaminants in the food chain, is currently dealing with the $\mathrm{Hg}$ emissions problem [14]. In September 2014, Poland, along with more than 140 other countries, signed the Minamata Convention, which seeks to reduce and ultimately ban the use of mercury and its compounds. The emphasis was primarily put on the prohibition of metallic mercury use in gold mines, but by 2020 this ban shall include all products containing mercury and its toxic compounds. For now, the ban does not include thimerosal, which is still used in some vaccines and cosmetic products. This does not mean that mercury will disappear completely. Certain compounds of this element will continue to be used in industry as catalysts as well as in commonly used technologies and scientific research $[3,8,15]$.

In Poland, the limits of mercury and its compounds content have been established for atmosphere [16], workplace [17], drinking water, soil, and feed [1820]. EU limits have been established for food, but only for fish and fish products [21]; however, the Joint FAO/WHO Expert Committee on Food Additives (JECFA) established a weekly intake of methylmercury compounds from all sources tolerable by healthy human organisms (Provisional Tolerable Weekly Intake, PTWI), and it is $1.6 \mu \mathrm{gHg} / \mathrm{kg}$ body weight (BW), which corresponds to $0.096 \mathrm{mg}$ per adult (60 $\mathrm{kg}$ weight), while the PTWI value for inorganic mercury is $4 \mu \mathrm{g} / \mathrm{kg} \mathrm{BW}$ (0.24 mgHg/adult) [22].

The main sources of mercury in humans are marineorigin products, especially fish and fish products [23-
25], although some quantities may come from animal production (milk, meat, eggs) - especially in industrial areas, or from animals fed with feed contaminated with mercury compounds [26-29]. Tables 1 and 2 show data concerning mercury content in various environmental components (air, soil, water, fuel, fertilizers, sewage, etc.) and biological material (plants, feed, animals, food) according to various foreign and Polish authors.

The effect of the copper industry on the environment in terms of mercury accumulation in soils, plants, animals, or even human organisms is little recognized. However, mercury is present in small quantities in copper ore deposits, generally less than $1 \mathrm{~g} / \mathrm{Mg}$, but in a layer of copper-bearing shale (Polkowice deposits) its content was up to $1.89 \mathrm{~g} / \mathrm{Mg}$ and in the Rudna extraction field up to $9.88 \mathrm{~g} / \mathrm{Mg}$ [30]. Certain amounts of metalliferous dusts (containing mercury compounds) are emitted from copper smelters (Legnica, Głogów, and Orsk) and from Żelazny Most in Rudna, Poland - one of the largest in the tailing ponds in the world [31].

The aim of our study was to evaluate the total mercury accumulation in plants and farm animals in the area of copper industry influence, i.e., in the central region of Legnica-Głogów Copper District (LGOM).

\section{Experimental}

\section{Study Area}

We conducted our study in the LGOM area, which covers 14 villages of the Lubin, Polkowice, and Głogów districts. These areas are located near the Głogów and Cedynia copper smelters (CS); the Lubin, PolkowiceSieroszowice, and Rudna copper mines/mining plants (MP); plus the ore enrichment plant (OEP) in Rudna. Mines, ore flotation plants, and smelters emit a lot of gaseous pollutants that contain metalliferous dusts (with mercury compounds). This is also the area where the tailing pond Żelazny Most and its wastes from copper ore mines is located. It covers an area of about 1,400 ha, and

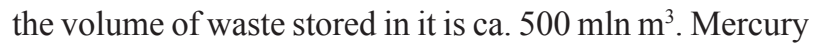
concentration of flotation tailings is $0.14-0.23 \mathrm{~g} / \mathrm{Mg}$, and in tank sludge supernatant it is $0.7 \mu \mathrm{g} \mathrm{Hg} \cdot \mathrm{dm}^{-3}$ on average [30-31]. Assuming an average $\mathrm{Hg}$ concentration in the waste of only $0.1 \mathrm{mg} \cdot \mathrm{kg}^{-1}$, its deposit in the disposal site would be about $50 \mathrm{Mg}$. Of course this is related to solid waste, but can also move to the liquid phase (aqueous) and then, through evaporation, get into the atmosphere. There are some data concerning total mercury content in the soil and drinking water of this region, confirming that the copper industry has impact on the local environment. Concentrations of $\mathrm{Hg}$ in soil samples ranged from 0.045 to $0.251 \mathrm{mg} \cdot \mathrm{kg}^{-1}$ [31] or even $0.57-4.64 \mathrm{mg} \cdot \mathrm{kg}^{-1}$ [32]. The permissible content of mercury in the soils from group A (protected areas) is $0.5 \mathrm{mg} \cdot \mathrm{kg}^{-1} \mathrm{DM}$, while in the soils from group B (at a depth of $0.3-15 \mathrm{~cm}$ ) it is $3 \mathrm{mg} \cdot \mathrm{kg}^{-1} \mathrm{DM}$, depending on water permeability [18]. Moreover, Barej et al. [33] reported that concentrations of total $\mathrm{Hg}$ in samples 
Table 1. The content of mercury in environmental material according to different authors.

\begin{tabular}{|c|c|c|}
\hline Material and country & Content & Source* \\
\hline $\begin{array}{l}\text { Air: Urban and industrial regions } \\
\text { (different countries) }\end{array}$ & $0.090-38 \mathrm{ng} \cdot \mathrm{m}^{-3}$ & Kabata-Pendias and Szteke (2012) \\
\hline Contaminated soils (Poland) & Mean $1.5 ; \max 4.6 \mathrm{mg} \cdot \mathrm{kg}^{-1}$ & Chojnacka et al. (2005) \\
\hline Contaminated soils (different countries) & $0.12-17,000 \mathrm{mg} \cdot \mathrm{kg}^{-1}$ & Kabata-Pendias and Szteke (2012) \\
\hline $\begin{array}{c}\text { Oceanic waters (North Atlantic and } \\
\text { North Pacific) } \\
\end{array}$ & Mean $0.20 \mathrm{ng} \cdot \mathrm{L}^{-1}$ & Driscol et al. (2013) \\
\hline Rivers water (Ghana) & $<1.0-11 \mu \mathrm{g} \cdot \mathrm{L}^{-1}$ & Adjei-Kyereme et al. (2015) \\
\hline Stream sediments (Poland, Silesia) & $<0.050-180 \mathrm{mg} \cdot \mathrm{kg}^{-1}$ & Pasieczna (2014) \\
\hline Coal (Poland) & Mean $0.074 ; \max 0.32 \mathrm{mg} \cdot \mathrm{kg}^{-1}$ & Klojzy-Kaczmarczyk and Mazurek (2013) \\
\hline Coal ash (China) & $0.13-4.8 \mathrm{mg} \cdot \mathrm{kg}^{-1}$ & Wang et al. (2006) \\
\hline Petroleum products (Poland) & $4.7-15 \mu \mathrm{g} \cdot \mathrm{kg}^{-1}$ & Albińska et al. (2006) \\
\hline Petrochemical products (USA) & $0.27-7100 \mu \mathrm{g} \cdot \mathrm{g}^{-1}$ & Wilhelm et al. (2000) \\
\hline Mineral-organic fertilizers (Poland) & $0.0030-2.8 \mathrm{mg} \cdot \mathrm{kg}^{-1}$ & Górecki et al. (2002) \\
\hline Feed phosphates (Poland) & $0.020-0.28 \mathrm{mg} \cdot \mathrm{kg}^{-1}$ & Hoffmann et al. (2004) \\
\hline Feed for poultry (Pakistan) & $0.14-2.4 \mathrm{mg} \cdot \mathrm{kg}^{-1}$ & Imran et al. (2014) \\
\hline Feeding stuffs (EU: different countries) & Mean $0.030 ; \max 1.3 \mathrm{mg} \cdot \mathrm{kg}^{-1}$ & $\begin{array}{l}\text { Mercury as undesirable substances in animal feed, } \\
\text { EFSA Journal } 654,1-76(2008)\end{array}$ \\
\hline Manure from farm animals (Austria) & $0.080-0.58 \mathrm{mg} \cdot \mathrm{kg}^{-1}$ & Sager (2007) \\
\hline $\begin{array}{l}\text { Compost: chicken manure }+ \text { spent } \\
\text { mushroom }+ \text { soil (Spain) }\end{array}$ & $0.29-0.86 ; \max 17 \mathrm{mg} \cdot \mathrm{kg}^{-1}$ & Restrepo-Sánchez et al. (2015) \\
\hline Municipal wastewater (Italy) & Mean $1.4 \mathrm{mg} \cdot \mathrm{kg}^{-1}$ & Goi et al. (2006) \\
\hline
\end{tabular}

*available from authors

of drinking water collected at the LGOM region (seven farmsteads) ranged $0.3-4.4 \mu \mathrm{g} \cdot \mathrm{dm}^{-3}$, while the acceptable limit is on the level of $1.0 \mu \mathrm{g} \cdot \mathrm{dm}^{-3}$.

Except for the dominant role of the copper industry in this region (LGOM), there is also agriculture, i.e., highly productive cultivated soils or small-scale livestock farming; however, this demonstrates a downward trend [34].

\section{Research Samples}

The research material consisted of consumption and fodder plants (e.g., wheat, potatoes, and hay), as well as animal origin material such as milk, blood, and hair of dairy cows (breeding in small herds, grazing), eggs, and hen muscles and livers (outdoor breeding). The material was collected in the autumn from small-scale farms in Grodowiec, Grodziszcze, Gwizdanów, Komorniki, Krzydłowice, Tarnówek, Brodów, Mleczno, Orsk, Pieszkowice, Rudna, Rynarcice, Toszowice, and Żelazny Most. The samples were collected twice from 1-2 farms in the mentioned villages, i.e., in 2014 and 2015 (with cow hair in 2015 only). A total of 280 biological samples were analyzed (plant and animal origin material).

Plants were collected into plastic bags (wheat, hay, cleaned potatoes), while the milk was derived directly from the cows (after milking). Blood samples for analysis were collected from the external jugular vein (vena jugularis externa), and the hair was cut out of the back part, then washed in water with detergent and rinsed in distilled water. Muscles (pectoral) and liver of laying hens (1-2 years old) were collected immediately after decapitation. Hen eggs were hard-boiled and egg albumen was mixed with egg yolk. Blood, milk, and potato samples were lyophilized. All concentrations of total mercury are given as $\mu \mathrm{g} \cdot \mathrm{kg}^{-1}$ wet weight (wet wt).

Similar material was not collected from other regions of the country (for comparative purposes), since mercury concentration in environmental and biological elements as well as in food is very differentiated, and it depends on numerous factors of natural and anthropogenic origin, which we demonstrated in our introduction and in Tables 1 and 2. Nevertheless, the results obtained in the two series of measurements were compared with the results of the studies carried out in this area (LGOM) in previous years (i.e., 2002 to 2007), and other studies by Polish and foreign authors.

\section{Analytical Techniques}

Analyses were performed using an atomic absorption spectrometer AMA 254 (Altec Ltd., Czech Republic) 
Table 2. The content of mercury in biological material and food according to different authors

\begin{tabular}{|c|c|c|}
\hline Material and country & Content & Source* \\
\hline Cereals: various species $(\mathrm{EU}-15)$ & $0.0010-0.019 \mathrm{mg} \cdot \mathrm{kg}^{-1}$ & SCOOP 3.2.11 (2004) \\
\hline Infant cereals (Spain) & $0.42-7.6 \mu \mathrm{g} \cdot \mathrm{kg}^{-1}$ & $\begin{array}{l}\text { Hernández-Martínez and Navarro-Blasco } \\
\qquad(2013)\end{array}$ \\
\hline Vegetables: various species (EU -15) & $0.00040-0.011 \mathrm{mg} \cdot \mathrm{kg}^{-1}$ & SCOOP 3.2.11 (2004) \\
\hline Potato tubers (Slovakia) & $0.015-20 \mathrm{mg} \cdot \mathrm{kg}^{-1}$ & Klimakova and Poracova (2011) \\
\hline Edible mushrooms (Czech Republic) & $0.25-13 \mathrm{mg} \cdot \mathrm{kg}^{-1}$ & Svoboda et al. (2006) \\
\hline Bee bodies (Poland) & $0.50-6.4 \max 23 \mu \mathrm{g} \cdot \mathrm{kg}^{-1}$ & Madras-Majewska and Jasiński (2005) \\
\hline Meat and fall (EU-15) & $0.0070-0.012 \mathrm{mg} \cdot \mathrm{kg}^{-1}$ & SCOOP 3.2.11 (2004) \\
\hline Sea and river fish (Germany) & $0.024-0.15 . \max 9.0 \mathrm{mg} \cdot \mathrm{kg}^{-1}$ & Schweinsberg (2003) \\
\hline Imported fish: tuna (New Zealand) & $0.0070-0.66 \mathrm{mg} \cdot \mathrm{kg}^{-1}$ & Thomson and Lee (2009) \\
\hline Seafood (Chile) & $0.070-1.9 \mathrm{mg} \cdot \mathrm{kg}^{-1}$ & Marko et al. (2014) \\
\hline Hen eggs, free range system (Poland) & mean $3.4 \mu \mathrm{g} \cdot \mathrm{kg}^{-1}$ & Barej et al. (2015) \\
\hline Eggs of Canada geese (USA) & $4.6 \pm 0.32 \mu \mathrm{g} \cdot \mathrm{g}^{-1}$ & Tsipoura et al. (2011) \\
\hline Cow milk (China) & $1.0-3.9 \mu \mathrm{g} \cdot \mathrm{kg}^{-1}$ & Zhang et al. (2007) \\
\hline Women breast milk (Brazil) & $<0.76-23 \mu \mathrm{g} \cdot \mathrm{L}^{-1}$ & Cunha et al. (2013) \\
\hline Human blood (Canada) & $0.58-4.2 \mu \mathrm{g} \cdot \mathrm{L}^{-1}$ & Lambrinos (2014) \\
\hline Human hair (EU - 17 countries) & $0.060-2.4 \mu \mathrm{g} \cdot \mathrm{g}^{-1}$ & Castano et al. (2015) \\
\hline Animal hair (Poland) & $0.0040-0.018 \mathrm{mg} \cdot \mathrm{kg}^{-1}$ & Dobrzański et al. (2007) \\
\hline Hair of wild fur animal (Canada) & $21-30 \mu \mathrm{g} \cdot \mathrm{g}^{-1}$ & Fortin et al. (2001) \\
\hline Food (human diet) USA & Mean $5.6 \mu \mathrm{g} \cdot \mathrm{kg}^{-1}$ & Iyengar et al. (2000) \\
\hline
\end{tabular}

*available from authors

to determine total mercury content directly in raw materials, regardless of $\mathrm{Hg}$ form. The limit of detection is $0.003 \mathrm{ng}$ of $\mathrm{Hg}$ per sample. Several reference materials were used for verification of the method: soil (Loamy clay, No. RTC-CRM052-050), grass (Rye grass, No. ERMCD281), and cow muscles (Bovine muscle, No. ERMBB184) manufactured by IRMM (Belgium). The certified reference materials were analyzed with recoveries ranging from 97.5 to $104 \%$.

\section{Statistical Analyses}

The results were analyzed statistically, the mean values and standard deviations for nine categories of plant and animal materials were calculated. The mean values between years (Series I and II) were compared using Student's t-test (computer software Statgraphics ver. 5.1) at the significance level of $\mathrm{p}<0.05$.

\section{Results and Discussion}

Table 3 presents the results of plant origin materials examination. The maximum content of $\mathrm{Hg}$ in cereals (wheat) was 5.20, and the mean concentrations in particular series were 1.42 and $1.50 \mu \mathrm{g} \cdot \mathrm{kg}^{-1}$. Thus, we noted a fourfold decrease of $\mathrm{Hg}$ content compared to previous results obtained almost 10 years ago [33]. Hg concentration in meadow grass (hay) was distinctly higher than in cereals. The maximum mercury content was $37.3 \mu \mathrm{g} \cdot \mathrm{kg}^{-1}$, and the average values in particular series were 17.3 and $13.9 \mu \mathrm{g} \cdot \mathrm{kg}^{-1}$, thus only a small difference in comparison to previous studies occurred [33]. The lowest concentration of mercury was found in potato tubers. The maximum content was $0.740 \mu \mathrm{g} \cdot \mathrm{kg}^{-1}$, and mean concentrations in particular years were quite similar (about $0.300 \mu \mathrm{g} \cdot \mathrm{kg}^{-1}$ ). It is difficult to compare these results, since previous studies relate to peeled tubers derived only in the area of Głogów Copper Mine (mean concentration of $\left.0.0900 \mu \mathrm{g} \cdot \mathrm{kg}^{-1}\right)$ [28].

Polish authors reported a wide range of $\mathrm{Hg}$ concentration in plants, e.g., in grass from contaminated areas from 0.04 to $4 \mathrm{mg} \cdot \mathrm{kg}^{-1} \mathrm{DM}$, in cereals (grain) from different countries from 3.4 to $20 \mu \mathrm{g} \cdot \mathrm{kg}^{-1} \mathrm{DM}$ [3], and in potatoes $0.6 \mu \mathrm{g} \cdot \mathrm{kg}^{-1}$ on average [35]. For comparison, the acceptable mercury content in basic feed materials (about $88 \%$ of dry matter) is $0.1 \mathrm{mg} \cdot \mathrm{kg}^{-1} \mathrm{DM}$ [36]. According to EFSA data [37], $\mathrm{Hg}$ content in complete feed mixture for terrestrial animal categories in the EU is $0.012-0.053 \mu \mathrm{g} \cdot \mathrm{kg}^{-1}$, on average. The EU legal act 
Table 3. Total mercury content in plant materials in $\mu \mathrm{g} \cdot \mathrm{kg}^{-1}$ wet wt.

\begin{tabular}{|c|c|c|c|c|}
\hline Series & Unit & Grain & $\begin{array}{c}\text { Meadow } \\
\text { grass }\end{array}$ & Potato \\
\hline \multirow{3}{*}{ I } & Mean & 1.42 & 17.3 & 0.350 \\
\cline { 2 - 5 } & SD & 1.70 & 7.30 & 0.140 \\
\cline { 2 - 5 } & Range & $0.200-5.20$ & $7.50-37.3$ & $0.160-0.700$ \\
\hline \multirow{2}{*}{ II } & Mean & 1.50 & 13.9 & 0.270 \\
\cline { 2 - 5 } & SD & 0.910 & 5.72 & 0.180 \\
\cline { 2 - 5 } & Range & $0.100-3.80$ & $8.90-33.6$ & $0.400-0.740$ \\
\hline \multirow{2}{*}{$\begin{array}{c}\text { Earlier } \\
\text { study }\end{array}$} & Average & $5.14^{*}$ & $18.5^{*}$ & $0.0900 * *$ \\
\cline { 2 - 5 } & Maximum & $6.67^{*}$ & $45.0^{*}$ & $0.700^{* *}$ \\
\hline
\end{tabular}

*acc. Barej et al. (2009); ** acc. Wyka et al. (2009)

concerning chemical contaminants in food does not include mercury, except in fish and fish products [38].

Mercury concentrations noted in animal origin products were generally lower than in plants (Tables 4 and 5). Maximum $\mathrm{Hg}$ content in raw milk was $0.400 \mu \mathrm{g} \cdot \mathrm{kg}^{-1}$, with similar means in both series $(0.230$ and $0.200 \mu \mathrm{g} \cdot \mathrm{kg}^{-1}$ ). In previous studies [33], mean content was 8 -fold higher. Maximum concentration in the blood of cows was $6.00 \mu \mathrm{g} \cdot \mathrm{kg}^{-1}$, with similar means in both series (about $1.80 \mu \mathrm{g} \cdot \mathrm{kg}^{-1}$ ). Previous studies conducted in other industrialized regions of Lower Silesia (near Wrocław) demonstrated an average $\mathrm{Hg}$ concentration in blood of cows on the level of $0.950 \mu \mathrm{g} \cdot \mathrm{kg}^{-1}$, while in their hair it was $2.49 \mu \mathrm{g} \cdot \mathrm{kg}^{-1}$ (maximum $6.20 \mu \mathrm{g} \cdot \mathrm{kg}^{-1}$ ) [39].

Low mercury concentration in milk samples (7-8 times lower than in blood) should be emphasized when evaluating the results of these analyses (cattle), while it shows the protective function of the mammary gland. There is no current legislation that sets acceptable limits of mercury content in milk, but, for example, average values of $\mathrm{Hg}$ in cow's milk (and milk products) in EU countries at the turn of 20th and 21st centuries ranged from 0.5 to $5 \mu \mathrm{g} \cdot \mathrm{kg}^{-1}$ [40]. Another good example of an environmental pollution bioindicator is toxic metals concentration in animal hair. The values obtained are relatively lower compared to other domestic animals [3, 41-42], but similar to the results of previous studies [39]. It is interesting that mercury content in horse hair is positively and significantly correlated with other investigated elements, such as arsenic, silicon, phosphorus, sulfur, and selenium [43].

Maximum $\mathrm{Hg}$ concentration in egg content was $3.50 \mu \mathrm{g} \cdot \mathrm{kg}^{-1}$, while average values in two subsequent series were on the level of 1.54 and $1.13 \mu \mathrm{g} \cdot \mathrm{kg}^{-1}$. Determined $\mathrm{Hg}$ concentration were 2-3 fold lower compared to previous studies of samples from this area [33]. Twice lower concentrations of $\mathrm{Hg}$ were found in the muscles of hens, and the maximum content was $1.80 \mu \mathrm{g} \cdot \mathrm{kg}^{-1}$. Compared to previous studies, determined concentrations were multiple lower, taking into account that the average value of $\mathrm{Hg}$ detected in earlier years was $6.00 \mu \mathrm{g} \cdot \mathrm{kg}^{-1}$ [44].
Table 4. Total mercury content in animal materials (cow) in $\mu \mathrm{g} \cdot \mathrm{kg}^{-1}$ wet wt.

\begin{tabular}{|c|c|c|c|c|}
\hline Series & Unit & Milk & Blood & Hair \\
\hline \multirow{3}{*}{ I } & Mean & 0.230 & 1.86 & ns \\
\cline { 2 - 5 } & SD & 0.120 & 1.51 & - \\
\cline { 2 - 5 } & Range & $0.100-0.400$ & $1.00-6.00$ & - \\
\hline \multirow{3}{*}{ II } & Mean & 0.200 & 1.77 & 2.88 \\
\cline { 2 - 5 } & SD & 0.130 & 0.360 & 1.16 \\
\cline { 2 - 5 } & Range & $0.100-0.400$ & $1.10-2.20$ & $0.100-6.20$ \\
\hline \multirow{2}{*}{$\begin{array}{c}\text { Earlier } \\
\text { study }\end{array}$} & Average & $1.65 *$ & $0.950 * *$ & $2.49 * *$ \\
\cline { 2 - 5 } & Maximum & $3.50^{*}$ & $2.00 * *$ & $6.52 * *$ \\
\hline
\end{tabular}

*acc. Barej et al.(2009); **acc. Dobrzański et al.(2009); nsno study

Table 5. Total mercury content in animal materials (hen) in $\mu \mathrm{g} \cdot \mathrm{kg}^{-1}$ wet wt.

\begin{tabular}{|c|c|c|c|c|}
\hline Series & Unit & Egg & Muscle & Liver \\
\hline \multirow{4}{*}{ I } & Mean & 1.54 & 0.660 & 2.63 \\
\cline { 2 - 5 } & SD & 0.950 & 0.510 & 3.91 \\
\cline { 2 - 5 } & Range & $0.300-3.50$ & $0.100-1.80$ & $0.400-16.0$ \\
\hline \multirow{3}{*}{ II } & Mean & 1.13 & 0.700 & 2.27 \\
\cline { 2 - 5 } & SD & 0.670 & 0.450 & 1.24 \\
\cline { 2 - 5 } & Range & $0.200-1.90$ & $0.100-1.60$ & $1.10-5.30$ \\
\hline \multirow{2}{*}{$\begin{array}{c}\text { Earlier } \\
\text { study }\end{array}$} & Average & $3.86^{*}$ & $6.00^{* *}$ & $7.10^{* *}$ \\
\cline { 2 - 5 } & Maximum & $6.90^{*}$ & $11.0^{* *}$ & $18.0 * *$ \\
\hline
\end{tabular}

*acc. Barej et al. (2009), ** acc. Kołacz et al. (2003)

However, an average $\mathrm{Hg}$ content in hen's liver samples was within a wide range of 0.400 and $16.0 \mu \mathrm{g} \cdot \mathrm{kg}^{-1}$, but the average values in both series were quite similar (between 2.27 and $\left.2.63 \mu \mathrm{g} \cdot \mathrm{kg}^{-1}\right)$. Mercury concentrations in previous studies were almost three-fold higher [44].

There is still a lack of literature in the field concerning mercury content in poultry products. An average $\mathrm{Hg}$ content in eggs in the EU countries at the turn of 20th and 21st centuries ranged from 1.3 to $2.0 \mu \mathrm{g} \cdot \mathrm{kg}^{-1}$ [40], although the level of $0.5-4.0 \mu \mathrm{g} \cdot \mathrm{kg}^{-1}$ was observed in backyard farming in Belgium [45]. The concentration of mercury in poultry tissues and organs depends on the housing system as well as on the quality of feed and water. For example, an average of $7.06 \mathrm{mg} \cdot \mathrm{kg}^{-1}$ of mercury was found in drinking water at a broiler farm in Saudi Arabia, which resulted in increased $\mathrm{Hg}$ concentration in liver samples of chickens up to a level of $1,167 \mu \mathrm{g} \cdot \mathrm{kg}^{-1}$ [46]. Mercury also easily accumulates in egg content, liver, and muscles when methylmercury is presented in the feed [26]. This can be prevented to a limited extent when feed additives containing humic compounds and 
aluminosilicates are supplemented [26, 47]. Another solution is selenium supplementation. Se is an antagonistic element to $\mathrm{Hg}$, but it can easily be overdosed and then is highly toxic in excess [1-3].

According to EFSA recommendations [22], the levels of $\mathrm{Hg}$ present in foods (other than fish and seafood) are of lower concern mainly because the forms of $\mathrm{Hg}$ present in these other foods are not methylmercury. Thus the maximum levels for $\mathrm{Hg}$ in foodstuffs were set only for fishery products and muscle meat of fish $\left(0.5-1.0 \mathrm{mg} \cdot \mathrm{kg}^{-1}\right)[38]$. Taking into consideration that the highest concentration of $\mathrm{Hg}$ determined for the present study were on the level of $37.3 \mu \mathrm{g} \cdot \mathrm{kg}^{-1}$ (meadow grass) and $16.0 \mu \mathrm{g} \cdot \mathrm{kg}^{-1}$ (laying hens liver), which is much lower than the acceptable content in fishery products, there is no possible health risk (mercury criterion) for animals and humans who consume food products from the investigated area.

\section{Conclusions}

The obtained results indicate a low level of total mercury pollution in an area of copper industry influence. The highest concentrations of $\mathrm{Hg}$ were found in grass and hen's liver samples. The lowest concentration of $\mathrm{Hg}$ was noted in cow's milk and chicken muscles $\left(<1 \mu \mathrm{g} \cdot \mathrm{kg}^{-1}\right)$. There was a many-fold decrease of mercury concentration in cereals, cow's milk, and poultry products (eggs, muscles, liver) in comparison to previous studies (200207 ), which indirectly proves the effective environmental efforts led by local authorities and industry.

The investigated copper industry does not pose a toxicological concern (mercury criterion) to the natural and agricultural environment in the area of its influence. However, periodic biomonitoring studies are necessary, considering physico-chemical and biological effects of this highly toxic element, as well as the EU guidelines concerning the restrictions in $\mathrm{Hg}$ emissions.

\section{Acknowledgements}

The study was conducted within the statutory research of the Faculty of Biology and Animal Science, Wroclaw University of Environmental and Life Sciences, and co-funded by the Leading National Research Center (KNOW) for the years 2014-18 for the Wroclaw Center for Biotechnology.

\section{References}

1. BERNHOFT R.A. Mercury Toxicity and Treatment: A Review of the Literature. J. Environ. Pub. Health. 2012:460508, 2012.

2. OLSON D.A. Mercury Toxicity Treatment \& Management, Ed. Ramachandran T.S. Available online: http://emedicine. medscape.com/article/1175560-treatment (accessed on 18.08.2016).
3. KABATA-PENDIAS A., PENDIAS H. Biogeochemistry of Trace Elements, $2^{\text {nd }}$ ed.; Wyd. Nauk PWN: Warsaw, Poland, 170, 1999 [In Polish].

4. ROONEY J.P. The retention time of inorganic mercury in the brain - A systematic review of the evidence. Toxicol. Appl. Pharmacol. 274 (3), 425, 2014.

5. AZEVEDO R., RODRIGUEZ E. Phytotoxicity of Mercury in Plants: A Review. J. Botany 2012, Article ID 848614 , http://dx.doi.org/10.1155/2012/848614.

6. CRESPO-LOPEZ M.E., MACEDO G.L., PEREIRA S.I., ARRIFANO G.P., PICANCO-DINIZ D.L., DO NASCIMENTO J.L., HERCULANO A.M. Mercury and human genotoxicity: critical considerations and possible molecular mechanisms. Pharmacol. Res. 60 (4), 212, 2009.

7. Mercury and Mercury Compounds. International Agency for Research on Cancer 58, 239, 1993 Available online: http:// http://www.inchem.org/documents/iarc/vol58/mono58-3. html (accessed on 18.08.2016).

8. DRISCOL C.T., MASON R.P., HING MAN CHAN, DANIEL J.J., PIRRONE N. Mercury as a Global Pollutant: Sources, Pathways and Effects. Environ. Sci. Technol. 47 (10), 4967, 2013.

9. UNEP. Global Mercury Assessment 2013: Sources, Emissions, Releases and Environmental Transport. UNEP Chemicals Branch, Geneva, Switzerland, 2013 Available online: http://www.unep.org/PDF/PressReleases/ GlobalMercuryAssessment2013.pdf (accessed on 18.08.2016).

10. UNEP. Global Mercury Assessment. UNEP Chemicals, Geneva, Switzerland, 2002 Available online: http://www. unep.org/gc/gc22/Document/UNEP-GC22-INF3.pdf (accessed on 18.08.2016).

11. GLODEK A., PANASIUK D., PACYNA J.M. Mercury Emission from Anthropogenic Sources in Poland and Their Scenarios to the Year 2020. Water Air Soil Poll. 213, 227, 2010.

12. PACYNA E.G., PACYNA J.M., FUDAŁA J., STRZELECKA-JASTRZĄB E., HŁAWICZKA S., PANASIUK D. Mercury emissions to the atmosphere from anthropogenic sources in Europe in 2000 and their scenarios until 2020. Sci. Total Environ. 370, 147, 2006.

13. PACYNA E.G., PACYNA J.M., STEENHUISEN F., WILSON S. Global anthropogenic mercury emission inventory for 2000. Atmos. Environ. 40 (22), 4048, 2006.

14. HASSAUER M., KAISER E., SCHNEIDER K., SCHUHMACHER-WOLZ U. Collate the literature on toxicity data on mercury in experimental animals and humans (Part I - Data on organic mercury). Supporting Publications 2012:EN-297, External scientific report prepared for EFSA, European Food Safety Authority, Parma, Italy 2012 Available online: http://onlinelibrary. wiley.com/doi/10.2903/sp.efsa.2012.EN-297/pdf (accessed on 18.08.2016).

15. Minamata Convention on Mercury. Available online: http://www.mercuryconvention.org/Portals/11/documents/ conventionText/Minamata $\% 20$ Convention $\% 20$ on $\% 20$ Mercury_e.pdf (accessed on 18.08.2016).

16. Regulation of the Minister of Environment of 26 January 2010 (J. L. 2010, No 16, pos. 87) 2010 [in Polish].

17. SAPOTA A., SKRZYPIŃSKA-GAWRYSIAK M. Mercury vapor and its inorganic compounds. Podst. Met. Oceny Środ. Pr. 65 (3), 85, 2010 [In Polish].

18. Regulation of the Minister of Environment of 9 September 2002 concerning the standards of soil quality and standards of earth quality (J. L. 2002, No 165, pos. 1359), 2002 [In Polish]. 
19. Regulation of the Minister of Health of 20 April 2010 (J.L. 2010, No 72, pos. 466) 2010 [in Polish].

20. Decree of the Minister of Agriculture and Rural Development of 11 October 2013 (J.L. 2014, pos. 203) 2014 [in Polish].

21. Commission Regulation (EU) No 420/2011 of 29 April 2011 amending Regulation (EC) No 1881/2006 setting maximum levels for certain contaminants in foodstuffs. Available online: http://eur-lex.europa.eu/LexUriServ/LexUriServ. do?uri=OJ:L:2011:111:0003:0006:EN:PDF (accessed on 18.08.2016).

22. Scientific Opinion on the risk for public health related to the presence of mercury and methylmercury in food. EFSA Journal, 10 (12), 2985, 2012.

23. BYKOWSKIP., DOBRZAŃSKIZ. Chemical contamination in fish diet of Polish consumers. Przem. Chem. 93 (10), 1763, 2014 [In Polish].

24. STORELLI M., BARONE G. Toxic Metals ( $\mathrm{Hg}, \mathrm{Pb}$, and Cd) in Commercially Important Demersal Fish from Mediterranean Sea: Contamination Levels and Dietary Exposure Assessment. J. Food Sci. 78, 362, 2013.

25. REILLY C. The persistent contaminants: lead, mercury, cadmium. In: Metal contamination of food, $3^{\text {rd }}$ ed.; Blackwell Publishing Company: Oxford, England, 94, 2002.

26. BAREJ R., DOBRZAŃSKI Z., POPIELA-PLEBAN E., BUBEL F., POLAK-JUSZCZAK L. Mercury Bioaccumulation in Eggs of Hens Experimentally Intoxicated with Methylmercury Chloride and Detoxified with Humic-Aluminosilicate Preparation. Braz. J. Poult. Sci. 17 (4), 531, 2015.

27. DURKALEC M., SZKODA J., KOLACZ R., OPALINSKI S., NAWROCKA A., ZMUDZKI J. Bioaccumulation of Lead, Cadmium and Mercury in Roe Deer and Wild Boars from Areas with Different Levels of Toxic Metal Pollution. Int. J. Environ. Res. 9 (1), 205, 2015.

28. WYKA J., ORZEŁ D., FIGURSKA-CIURA D., BRONKOWSKA M., STYCZYŃSKA M., ŻECHAŁKOCZAJKOWSKA A., BIERNAT J. Evaluation of vegetable products contamination with mercury in Legnica-Głogów area. Bromatol. Chem. Toksyk. 42 (2), 189-193, 2009 [In Polish].

29. ZHANG L., WONG M.H. Environmental mercury contamination in China: Sources and impacts. Environ. Int. 33, 108, 2007.

30. PIESTRZYŃSKI A., Monografia - KGHM Polska Miedź S.A., Wyd. KGHM Lubin, 2007 [In Polish].

31. CZABAN S., KOŁACZ R., DOBRZAŃSKI Z., BUBEL F., OPALIŃSKI S., DURKALEC M., GRUSZCZYŃSKI M. Mercury content in the area of the "Żelazny Most" tailings pond. Przem. Chem. 92 (7), 1268, 2013 [In Polish].

32. CHOJNACKA K., CHOJNACKI A., GÓRECKA H., GÓRECKI H. Bioavailability of heavy metals from polluted soils to plants. Sci. Total Environ. 337 (1), 175, 2006.

33. BAREJ R., KWAŚNICKI R., CHOJNACKA K., BOLANOWSKI J., DOBRZAŃSKI Z., POKORNY P. Mercury Content in Rural and industrial Regions in Lower Silesia. Pol. J. Environ. Stud. 18 (4), 547, 2009.

34. Statistical Yearbook of Lower Silesia, GUS Wrocław, 2015 [In Polish].
35. KABATA-PENDIAS A., SZTEKE B. Trace elements in geo- and biosphere, 1st ed.; Publishing House IUNG-PIB: Puławy, Poland, 166, 2012 [In Polish].

36. Regulation of the Minister of Agriculture and Rural Development of 6 February 2012 concerning the content of undesirable substances in feed (J.L. 2012, pos. 203) 2012 [In Polish].

37. Mercury as undesirable substance in animal feed. Scientific opinion of the Panel on Contaminants in the Food Chain. The EFSA Journal 654, 1, 2008 Available online: http:// www.efsa.europa.eu/sites/default/files/scientific_output/ files/main_documents/654.pdf (accessed on 18.08.2016).

38. Commission Regulation (EC) no 1881/2006 of 19 December 2006 setting maximum levels for certain contaminants in foodstuffs. Available online: http://eur-lex.europa.eu/eli/ reg/2006/1881/oj (accessed on 18.08.2016).

39. DOBRZAŃSKI Z., SZULC T., KUPCZYŃSKI R., KUCZAJ M. Study on a content of mercury in hair, milk and blood of cows housed in an urbanized area. EJPAU ser. Vet. Med. 12 (2), 2009.

40. Assessment of the dietary exposure to arsenic, cadmium, lead and mercury of the population of the EU Member States. SCOOP 3.2.11 2004 Available online: http:// ec.europa.eu/food/safety/docs/cs_contaminants_catalogue_ scoop_3-2-11_heavy_metals_report_en.pdf (accessed on 18.08.2016).

41. SAKAI T., ITO M., AOKI H., AIMI K., NITAYA R. Hair mercury concentrations in cats and dogs in Central Japan. Brit. Vet. J. 151, 215, 1995.

42. DOBRZAŃSKI Z., FILISTOWICZ A., PRZYSIECKI P., FILISTOWICZ A., NOWICKI S., WALKOWIAK K., CZYŻ K. Mercury bioaccumulation in hair and skin of arctic foxes (Vulpes lagopus) and silver foxes (Vulpes vulpes) in rural and urbanized region. Czech J. Anim. Sci. 59 (10), 480, 2014.

43. BUDZYŃSKA M., KRUPA W., SOŁTYS L., SAPUŁA M., KAMIENIAK J., BUDZYŃSKI M. Poziom biopierwiastków w sierści koni czystej krwi arabskiej. Annales UMCS Lublin, sec. EE, 24 (26), 199, 2006 [In Polish].

44. KOŁACZ R., DOBRZAŃSKI Z., GÓRECKA H., MORYL A., GRUDNIK T. Content of heavy metals in the tissues of hens kept in copper industry area. Acta Agrophysica 1 (2), 263, 2003 [In Polish].

45. WAEGENEERS N., HOENIG M., GOEYENS L., DE TEMMERMAN L. Trace elements in home-produced eggs in Belgium: levels and spatiotemporal distribution. Sci. Total Environ. 407 (15), 4397, 2009.

46. HUSSEIN H.K., ABU-ZINADAH O.,A., EL-RABEY H.A., MEERASAHIB M.F. Estimation of some heavy metals in polluted well water and mercury accumulation in broiler organs. Braz. Arch. Biol. Technol. 56 (5), 2013. http://dx.doi. org/10.1590/S1516-8913201300050000.

47. ZRALÝ Z., PÍSAŘÍKOVÁ B., NAVRÁTILOVÁ M. The effect of humic acid on mercury accumulation in chicken organs and muscle tissues. Czech J. Anim. Sci. 53 (11), 472, 2008. 